\title{
India two Wheelers Go Electric-Setting Stage for the E-Revolution
}

\author{
S. Seethalakshmi, K. Shyamala
}

\begin{abstract}
The Automobile industry across the globe is witnessing a transition. The United Nation's Convention on Climate change 2015, has set tall orders for all the countries to reduce the carbon imprint to save the globe. Transportation sector accounts for $70 \%$ of the use of the fossil fuels world over. So the countries across the globe are shifting to Electric Vehicles for mobility. India has initiated Policy measures prescribed by NITI AYOG the think tank of India to convert to $100 \%$ Electric vehicles by 2030. The Indian Automobile market is dominated by two wheelers which accounts for nearly $80 \%$ of the total market share for vehicles in India. The Electric revolution therefore has to begin with and be geared by the Two wheelers automotive market.

This article explores whether the Indian market is prepared for the electrical transition on two wheels. Although the Electric two wheelers are beset with several limitations the thrust is on reducing $\mathrm{CO} 2$ emissions and also to reduce the dependence on the fossil fuel imports. This paper consolidates the present Eco system for the Electric Two wheelers market in India and the road ahead. The study throws light on all the aspects relating to manufacturing and development of the ecosystem for $E$ - Two wheelers.

The article analyses whether there is awareness among public about the need to switch over to electric two wheelers to mitigate the effects of pollution. It analyses the factors that could influence the decision of purchasing electric two wheelers. The study also tries to identify the features that the electric vehicle users look for in the new electric models. This study is most relevant in the sunrise sector of electric vehicles which have made debut in the Indian market in 2015 only. The study gains significance because the Electric two wheeler market in India is in infancy and this study will throw some light on the market reaction to the E- revolution.
\end{abstract}

Key words: Electric two wheeler, ICE vehicles, Lion vehicles

\section{INTRODUCTION}

The Automobile industry across the globe is witnessing a transition. The United Nation's Convention on Climate change 2015, has set tall orders for all the countries to reduce the carbon imprint to save the globe. Transportation sector accounts for nearly $70 \%$ of the use of the fossil fuels world over. So the countries across the globe are shifting to Electric Vehicles.

INDIAN SCENARIO:

Revised Manuscript Received on September 10, 2019.

Dr. S. Seethalakshmi, Associate Professor, Department of Commerce, SDNB Vaishnav College for women, Chennai, Tamil Nadu, India.

(Email: seethasdnbv@yahoo.com)

Dr. K. Shyamala, Assistant Professor and HOD - B. COM-Corporate Secretary ship, (Finance), S.D.N.B.Vaishnav College for Women,Chromepet, Chennai, Tamil Nadu, India.

(Email: saatvikram@gmail.com)
As a member country of UNO, India has committed on the United Nations Framework Convention on Climate Change to shift to Electric vehicles by 2030.

- India houses 13 out of the 20 most polluted cities in the world ${ }^{[1]}$.

- Indian auto industry is the $4^{\text {th }}$ largest in the world next to China, USA, and Japan ${ }^{[2]}$

- India is the biggest importer of crude oil and transport sector the major consumer ${ }^{[3]}$.

- India is surplus in electricity generation since 2015.

Therefore India has to make rapid shift from ICE vehicles (Internal Combustion Engine vehicles that operate on Diesel and Petrol) to EV(Electric Vehicles).

The predominant reasons ushering the transition to Electric Vehicles (EV) are:

$>\quad$ To reduce the crude oil imports and dependence on fossil fuels.

$>\quad$ To provide cost effective transportation in the long run

$>\quad$ To reduce air pollution \& noise pollution and create a clean environment.

$>\quad$ To tap the global opportunity in EV market.

$>\quad$ To facilitate growth and manufacturing capacity in the sunrise sector

$>$ To utilise the skilled manpower in the manufacturing automobile sector

$>\quad$ To identify green and cheaper energy sources

In this context this article explores whether the Indian market is prepared for the electrical transition on two wheels.

\section{OBJECTIVES OF THE STUDY}

Part 1- Discussion -E- Vehicle Ecosystem for two wheelers in India

1. To consolidate the information on the Eco- system for the Electric Two wheelers.

2. To throw light on all the dynamics of ecosystem for E- Two wheelers.

\section{Part 2- The Survey}

3. To study the demographic profile of the Two wheeler users.

4. To know the awareness and preference for E2 wheelers in the study domain.

5. To identify the factors influencing consumers decision to purchase E-2 wheelers. 
6. To find the relationship between demographic profile and decision making factors.

\section{RESEARCH METHODOLOGY}

The study is confined to Chennai City only. Since the population for the survey is very large Random sampling of a sample size of 100 is taken for the survey. Data was collected during August 2019. Primary Data collected through Survey method from the respondents and the data was collected using a well structured Questionnaire. The secondary data was collected from journals, magazines, books, articles, research papers and websites.Percentage analysis, Factor Analysis, ANOVA, T-test tools used to analyse the data.

\section{THE DISCUSSION: E- VEHICLE ECOSYSTEM FOR 2 WHEELERS IN INDIA}

The Two wheeler segment holds nearly $80 \%$ share of the automobile sector in India ${ }^{[4]}$

Therefore to reduce the carbon imprint

- It is essential to focus on the two wheeler segment

- People should be encouraged to use Public transport and Shared transport systems.

- Vehicles should use only clean energy sources to reduce pollution

The future of the EVs in India lies on the two wheeler segment because it is a wide market. Close to 20 million Two wheelers are sold annually in India. The two wheeler segment is expected to drive the change because of its volume and scale of operation. The growing middle class and young population have impelled the growth of this sector. India is also a prominent auto exporter and growth potential is very high. Electric 2-wheelers were introduced in India in 2015 and sales have shown a steady growth.

Table -1 - Growth in demand for EV two wheelers from 2015.

\begin{tabular}{|c|c|c|c|}
$\begin{array}{c}\text { EV SALES } \\
\text { IN INDIA }\end{array}$ & $\begin{array}{c}2015-16 \\
\text { (Nos.) }\end{array}$ & $\begin{array}{c}2016- \\
17(\text { Nos. })\end{array}$ & $\begin{array}{c}2017- \\
18(\text { Nos.) }\end{array}$ \\
\hline $\begin{array}{c}\text { E 2 } \\
\text { WHEELERS }\end{array}$ & 20,000 & 23,000 & 54,800 \\
\hline $\begin{array}{l}\text { Source : SIAM -Society of IndianAutomobile } \\
\text { Manufactureres- Induatry composition [5] }\end{array}$
\end{tabular}

\section{THE TRANSITION TO ELECTRIC TWO WHEELERS} AND THE CHALLENGES

Electric two wheelers are plug in electric vehicles on two wheels. Electricity is stored on board in rechargeable batteries which drive the electric motors. The transition to EVs will require technological shift in manufacturing technology from ICE to EV and supportive charging infrastructure. China leads the world in Electric scooter sales comprising 9.4 million pa. High prices, Limited range , Lack of Charging facility, Kilo meters per charge, Speed and Acceleration have been impediments to the electric motors and scooters market. These impediments have not deterred the countries from tapping this golden opportunity to meet the global demand for Electric vehicles.

India has to adapt to the change or otherwise it will miss the two wheeler revolution and fall prey to the Chinese automobile MNCs. NITI Ayog has cautioned the 2 wheeler manufacturers to pull up the socks or lose their share to the Indian start-ups who are buoyant and vibrant in the two wheeler segment.

The major concerns of the Indian OEM manufacturers in shifting to the EV models are

- $\quad$ Electric Vehicles have to rely heavily upon the Indian Electric distribution system which has been plagued by high distribution losses, inadequate coverage, low cost recovery, less investment in infrastructure.

- $\quad$ Electric Vehicles need rechargeable Lithium ion batteries to drive the electric motors. The Lithium ion batteries have high power density, are lighter, have lower self Discharge rate and have longer life than Ni-Cad ion batteries and conventional Acid batteries.

- Chilie,China,Argentina are home to world's highest Lithium reserves. Indian Lithium resources are scanty. India could become a major importer of Lithium batteries from China for meeting the EV dreams.

- Indian customers are extremely price sensitive. Lithium batteries are costlier and add more than $30 \%$ to the cost of the vehicle. The cost of Electric two wheelers offering equivalent features is almost double the ICE two wheelers.

- The eco system is still in infancy. The giant OEM manufacturers are sceptical about this ambitious target of $100 \%$ conversion to EVs by 2030 . The charging system for the Electric vehicles is crucial for gaining the consumer's confidence.

- The Automobile industry gives employment opportunity to more than 10 million people in the country. However the Automobile industry employment situation will be affected during the transition period.

\section{DYANAMICS OF SHIFTING TO 2-WHEELER EV ECOSYSTEM}

> OPERATIONAL COSTS:- EVs are very economical Choosing an EV over ICE will save on the operational cost for the two wheeler user. The Diesel/ Petrol cost per kilo meter on ICE works out to Rs. 1.5 to Rs. 2 per kilo meter. In an EV the cost of charging is several times lesser. It works out to an average cost of Rs. 0.06 to 0.4 per kilo meter. There are no additional maintenance costs in an Electric Vehicle ${ }^{[6]}$

\section{VEHICLE PRICE (INITIAL INVESTMENT) :- EVs are highly priced}

Electric two wheelers with home plug in and slow recharge facility (6-8 hrs for recharge) are not very expensive. They can ideally serve the requirement of all small distance commuters. Such vehicles are priced at between Rs. 25,000 and Rs. 60,000 depending upon the additional features offered. Enhanced Electric scooters and power bikes have been designed to perform on par with the ICE vehicles in terms of speed, acceleration, distance per charge, fast recharge feature etc. Therefore such E-Power bikes and Enhanced e- scooters are priced higher. The price

Published By: 
is in the range of Rs.1,00,000 to 3,00,000.

This difference in pricing of EVs can be off-set over a few years on savings in operational cost. Manufacturers offer many purchase options with monthly payment facility. With more Research and Development happening in automobile industry, costs are likely to come down and alternate batteries and power storage mechanisms will evolve.

\section{$>\quad$ CHARGING OPTIONS:}

World over EVs have just 2 charging options

1. Plug in Charging stations 2. Swappable batteries

Most electric two wheelers prefer using standard slow charges which can be conveniently charged at any plug point. Home plug-ins (Private charging) is most convenient way of charging an EV. It normally takes $6-8 \mathrm{hrs}$ to fully charge an E- 2 wheeler .

Public Charging Stations (PCS) are ideally positioned in Parking places, Restaurants, Malls, Super Markets, Coffee shops etc. Charging stations are designed to dispatch AC and DC power. DC chargers are however much costlier than AC charger installations but can charge in 30 mins.

Swappable battery stations is most convenient option in Two wheeler EV segment. The best feature of battery swapping is the ultimate convenience and overall price.

The modularity of the set up is a compact storage compartment of size of a small refrigerator for batteries that can charge 12 to 15 batteries in 4 hrs with 15 Amps power supply. The swapping stations are set up in all areas and can be tracked on the GPS facility in the EV. The drained batteries are swapped with charged ones by the service station operator. The swapping models do not require much investment in space and can be handled as an additional business by existing traders or businessmen.

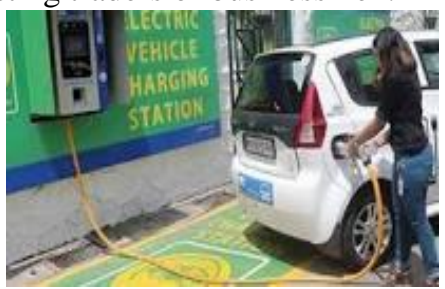

Plug in - Charging

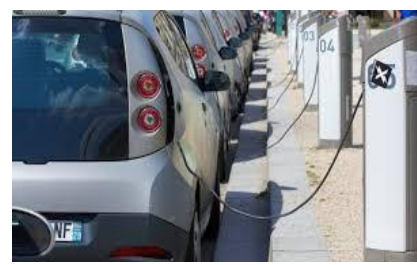

Multiple - Public charging points

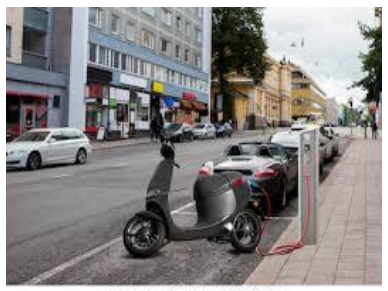

Public charging point

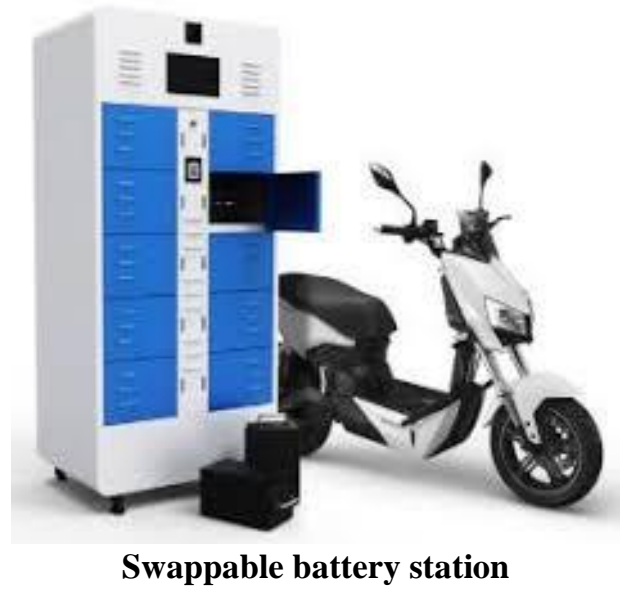

$\begin{array}{cl}\text { EVS: } & \text { SETTING UP PUBLIC CHARGE POINTS FOR } \\ \text { • } & \text { Setting up public charging stations have been de- }\end{array}$ licensed by the Central Government

- $\quad$ Govt. has prescribed one charge station for every 3 kms X $3 \mathrm{kms}$ radius and every $25 \mathrm{kms}$ on either side of a Highway

- Residential and Commercial buildings should provide EV charging infrastructure.

The transition from ICE vehicles to EVs largely depends upon the development of the charging infrastructure. Several private players and manufacturers are already into the market. The investment in the facility on the other hand depends on the potential for the EVs in the market.

$>$ FAME : FASTER ADOPTION AND MANUFACTURING OF EVs:

The Union Cabinet approved the proposal for the implementation of a scheme titled FAME-II India - Faster Adoption and Manufacturing of Electric Vehicles - Phase II for the promotion of Electric mobility across the country. Government has announced an outlay of Rs. 10,000 crores under the scheme to boost the Electric mobility, of which 1000 crores have been set aside for setting up E-charging stations across India. Incentive of Rs. 10,000 per $\mathrm{KW}$ is offered to OEM vehicles manufacturers based on the size of their batteries. States have been asked to come up with their own EV policy.

\section{STATE GOVERNMENT SUPPORT:}

The States are in sync with the Central Government's policy to promote Electric vehicles with a mix of incentives, sops and ecosystem. Karnataka, Delhi, Uttar Pradesh, Maharashtra , Telangana, Andhra Pradesh, Kerala and Uttarakhand have a policy in place

The Karnataka Govt. intends to make Karnataka the Electric Vehicle capital of India.

$>$ MAJOR PLAYERS IN TWO WHEELER MANUFACTURING SEGMENT: 


\begin{tabular}{|l|l|l|l|l|}
\hline & Top 5 two wheeler Manufacturers & Motorcycle & Scooter Sales & $\begin{array}{l}\text { Total } \\
\text { Sales }\end{array}$ \\
\hline 1 & Hero Motor Corp Ltd & 3744181 & 391019 & 4135200 HERO ELECTRIC PHOTON, NYX E5 \\
\hline 2 & Honda Motorcycle \& Scooter India (P)Ltd & 1113801 & 2182860 & 3296661 HONDA RCX 125 \\
\hline 3 & TVS Motor Company Ltd & 529721 & 645020 & 1619439 TVS CREON \\
\hline 4 & Bajaj Auto Ltd & 1287133 & - & 1287133 BAJAJ URBANITE \\
\hline 5 & India Yamaha Motor Pvt Ltd & 227002 & 198385 & 425387 \\
\hline
\end{tabular}

The major players in the two wheelers manufacturing segment are Hero Motors(39\%), Honda MSI(29\%), TVS Motors(19\%), and Bajaj (12\%).

The impact of the transition will be faced by these major players who have made huge investments in the manufacture of ICE two wheelers, and are also left with huge pile of raw materials, components, and finished stock. They consider 2030 prescribed by NITI Ayog as an unrealistic deadline for penetration. The shift in technology and sudden switch over will cost a bomb and could be disruptive. EVs cannot offer superior performance than the same cost ICE vehicles. It will be a great challenge to the major players.

However almost all the major players have made their entry in the EV market with one or two models launched. The transition will require massive investments in technology, skilled human resource, and supportive infrastructure. Proper timing, Pricing and assessment of the market are critical to their success.

\section{$>\quad$ INDIAN START UPS IN THE FORAY}

Most interesting part of the EV transformation is the contribution of many Indian start-ups which have eyed on the highly potential EV market in India. The Start ups are very positive in their outlook and are fascinated about the market response to the E-two wheelers launched in the market.

Some of the successful EV start-ups that are spearheading India's switch to clean energy are Okinawa, Ather Energy, Avan Motors, Tork motors, Revolt Intellicorp, Twenty Two motors, Ultra Violettee Automotive, Ampere Motors, PuRE energy, YULU micro mobility, Gemopai Electric. These start-ups have made a brisk entry in the two wheeler segment.These start-ups have First mover advantage and culture is very encouraging. Most of the start ups have production in thousands of units and a few in Lakhs. There has to be phenomenal progress in production to meet the 2 -wheeler demands of the country.

\section{THE SURVEY \& MAJOR FINDINGS}

To find the market response to EV- 2 wheelers, nearly 100 two wheeler users in Chennai were surveyed. Reliability test on the sample surveyed revealed Cronbach's Alpha value of 0.971 testifying the reliability of the sample surveyed.

\section{THE DEMOGRAPHIC PROFILE OF THE RESPONDENTS:}

Gender:

$64 \%$ of the survey respondents were Male and $36 \%$ were Female

\section{Age wise Distribution:}

Majority $32 \%$ fall in the age group of 30-40years,

Monthly Income wise Distribution:

$36 \%$ earn between Rs.10,000- 20,000 pm.

\section{AWARENESS AND PREFERENCE FOR E- VEHICLE IN THE STUDY DOMAIN}

- $\quad 87 \%$ of the respondents are willing to contribute to a greener environment.

- $\quad 85 \%$ of the users are Aware of the presence of Electric two wheelers, the advantages and limitations of using them.

\section{- $\quad 92 \%$ are willing to shift to electric vehicles}

\section{THE FACTORS INFLUENCING DECISION TO PURCHASE E-2 WHEELER}

Factor analysis tool was applied on the data collected to find the factors influencing decision of purchase. The result of KMO and Bartlett's Test statistical values were significant at 5\% level and factor Analysis is applied on 16 variables (No.18-33). 
Factor 1: Economy Factors

\begin{tabular}{|c|c|c|c|c|c|c|c|c|}
\hline Var No & 22 & 23 & 24 & 18 & 25 & 26 & 27 & 32 \\
\hline Variable & $\begin{array}{c}\text { Finance- } \\
\text { EMI }\end{array}$ & $\begin{array}{c}\text { Mileage- } \\
\text { Kms /Rs. }\end{array}$ & $\begin{array}{c}\text { Speed - } \\
\text { Kmph }\end{array}$ & Price & $\begin{array}{c}\text { Kms per } \\
\text { fill/ rechg }\end{array}$ & $\begin{array}{c}\text { Maintenance } \\
\text { cost pa }\end{array}$ & $\begin{array}{c}\text { Storage } \\
\text { space }\end{array}$ & $\begin{array}{c}\text { Refill } \\
\text { facility }\end{array}$ \\
\hline Fa. Loadg & 0.737 & 0.542 & 0.681 & 0.854 & 0.587 & 0.845 & 0.739 & 0.84 \\
\hline
\end{tabular}

Factor 2: Design \& Aesthetic Factors

\begin{tabular}{|l|c|c|c|c|}
\hline VNo. & 9 & 30 & 28 & 31 \\
\hline Variable & Colour of the vehicle & Acceleration & Sales \& Service network & Design Aesthetics \\
\hline F.Loadg & 0.773 & 0.788 & 0.684 & 0.576 \\
\hline
\end{tabular}

Factor 3: Social Fators

\begin{tabular}{|l|c|c|c|c|}
\hline Var No & 19 & 20 & 21 & 33 \\
\hline Variable & Brand & Safety & Weight of the Vehicle & Environ friendly \\
\hline Factor Loadg & 0.627 & 0.846 & 0.833 & 0.648 \\
\hline
\end{tabular}

Factor analysis reveals that the factors influencing two wheeler purchases can be broadly categorised into Economy, Design \&Aesthetics and Social factors. Based on the factor loadings we can conclude that the most influencing factors of purchase are Price, Maintenance cost, Refill facility, Safety and Weight of the Vehicle.

Association Between Decision Making Factors \& Demographic Profile - ANOVA

\begin{tabular}{|c|c|c|c|c|c|}
\cline { 2 - 5 } $\begin{array}{l}\text { ANOVA } \\
\text { TABLE }\end{array}$ & $\begin{array}{l}\text { Maintainance } \\
\text { and Gender }\end{array}$ & $\begin{array}{l}\text { Mileage and } \\
\text { Qualification }\end{array}$ & $\begin{array}{l}\text { Safety and } \\
\text { Gender }\end{array}$ & $\begin{array}{l}\text { Weight of Vehicle- and } \\
\text { Academic qualification }\end{array}$ & $\begin{array}{l}\text { Color of Vehicle- and } \\
\text { Gender }\end{array}$ \\
\hline F & 0.003 & 0.007 & 0.049 & 0.04 & 0.014 \\
\hline
\end{tabular}

Table values of One-Way table revealed that there is Association between Demographic profile of

- Gender and Annual maintenance, Safety concern and Colour of the vehicle

- Academic Qualification and Mileage and Weight of vehicle consciousness

\section{T-TEST - ONE-SAMPLE STATISTICS \& RESULTS}

\begin{tabular}{|c|c|c|c|c|c|}
\hline Var. No. & VAR 34 & VAR 35 & VAR 36 & VAR 37 & VAR 38 \\
\hline Mean & 2.58 & 3.25 & 2.6 & 2.88 & 2.96 \\
\hline RANK & 5 & 1 & 4 & 3 & 2 \\
\hline
\end{tabular}

Some of the models available in the market with their features- Price, Time for recharge, Distance per recharge, Max speed, GPS, Geo fencing, Acceleration, Android touch, Cloud service etc were provided to the respondents without disclosing the vehicle brand. They were asked to rank based on their preference. $\mathrm{T}$-test mean score based ranking has indicated highest preference for Honda (Rank1), Okinawa (Rank2), Ather (Rank3), TVS(Rank 4), Hero ( Rank5). This reveals that even start-ups have great opportunity to tap the E- 2-wheelers market.

\section{MAJOR FINDINGS OF THE SURVEY:}

1. The survey of 100 respondents on their usage pattern of the two wheelers revealed:

$>\quad$ Majority 2- wheeler users drive a distance of 11$20 \mathrm{kms}$ per day,

$>\quad$ The Average Speed of majority respondents is 41$60 \mathrm{kmph}$,

$>\quad$ The majority service periodicity is Half yearly and

$>\quad$ The majority own ICE 2-wheelers priced between Rs.40,000- 60,000.

Electric variants of 2 wheelers meeting these specifications are available in the market. Therefore it is anticipated that the E-2-wheelers will match the market demand.

2. Survey of awareness \& willingness to shift to Etwo wheelers revealed
85\% of the users are Aware of the presence of Electric two wheelers, the advantages and limitations of using them and $92 \%$ are willing to shift to electric vehicles

3. Important Factors influencing purchase decision of Two wheelers are

$>\quad$ Classified into 3 :Economy factors, Design \& Aesthetic factors, Social factors

$>$ Economy factors as Price, Maintenance, Refill facility_influence purchase decision

$>$ Social facors of Safety and Weight of the Vehicle influence the purchase decision

4. Analysis of Association between Demographic profile and Factors influencing purchase revealed presence of association between

$>\quad$ Gender and Annual maintenance, Safety concern and Colour of the vehicle

$>\quad$ Academic Qualification and Mileage and Weight of vehicle consciousness

\section{CONCLUSION}

The present scenario may not be a good guide to understand the road to the future of the Electric two wheelers as they are still in evolutionary stage. The existing 
market leaders are sceptical about the switch over. But numerous start ups mushroom to reap the opportunity. The EV industry is both a great opportunity and challenge to the Indian Automobile Industry. It is imperative for India to surf though the Challenge and become a leader in the global EV market. Government supports in the form of fiscal and financial incentives also support the eco system.

The market survey of sample respondents has revealed a highly favourable response to introduction of E-2wheelers in the market. Consumers are prepared for the shift to the E2 wheelers. To conclude, Electric Vehicles is a change driver. EV industry is in infancy and poses lot of opportunities for India, which is a very big market by itself. India should be able to overcome the shortcomings, face the challenge and meet the target of going towards $100 \%$ Electric mobility. There will be lot of savings in Foreign exchange on import of crude oil. India will have opportunity to export Electric vehicles. Employment opportunity in Automobile sector will increase. India will identify and explore alternate renewable energy sources through Research and Development. India will become a world leader in Electric Vehicles by 2030 if it adopts itself and exploits the opportunity.

\section{REFERENCE}

1. https://en.wikipedia.org/wiki/List_of_mostpolluted cities by particulate matter concentration

2. https://www.ibef.org/industry/india-automobiles.aspx

3. https://en.wikipedia.org/wiki/List of countries by oil $\mathrm{i}$ $\underline{\text { mports }}$

4. http://www.siamindia.com/statistics.aspx?mpgid=8\&pgid $\underline{\text { trail }=12}$

5. https://www.drivespark.com/four-wheelers/2018/electricvehicle-india-sales-performance-policies-growthdemand-more-026712.html

6. https://www.pluginindia.com/ebikessavings.html

7. https://powermin.nic.in/sites/default/files/webform/notice s/scan0016\%20\%281\%29.pdf 